\title{
Field and Growth Chamber Evaluation of Powdery Mildew Disease on Deciduous Azaleas
}

\author{
Michael C. Long ${ }^{1}$ \\ Department of Horticultural Science and Landscape Architecture, Purdue \\ University, West Lafayette, IN 47907
}

Stephen L. Krebs ${ }^{2}$

David G. Leach Research Station of the Holden Arboretum, 1890 Hubbard Road, Madison, $\mathrm{OH} 44057$

\author{
Stan C. Hokanson ${ }^{3,4}$ \\ Department of Horticultural Science, University of Minnesota, 258 Alderman \\ Hall, 1970 Folwell Avenue, St. Paul, MN 55108
}

Additional index words. Rhododendron subgen. Pentanthera G. Don, disease resistance breeding

\begin{abstract}
Forty-one deciduous azalea (Rhododendron subgen. Pentanthera G. Don) cultivars were assessed for powdery mildew (PM) resistance in a two-location, 3-year field trial. Disease severity (percent leaf area affected) on abaxial leaf surfaces was used to rate the level of field resistance. This measure was proportional to $(r=0.83)$ but higher than estimates from corresponding adaxial surfaces. Eleven of these cultivars $(27 \%)$ appeared to be highly resistant under field conditions, i.e., evidence of PM on the leaves was zero or near zero. Twenty-three of the cultivars evaluated in the field experiment were also evaluated in a growth chamber experiment. In contrast to the field study, PM was more severe on the adaxial leaf surface in the growth chamber but still highly correlated with the abaxial response $(r=0.93)$. Based on adaxial disease scores, no cultivars in the growth chamber experiments were completely resistant. Growth chamber disease ratings based on either leaf surface were predictive of field performance $\left(r^{2}=0.62\right)$, suggesting use of the chambers could serve as a low-cost, off-season, early selection component of a deciduous azalea PM resistance breeding program.
\end{abstract}

Powdery mildew (PM) is a common foliar disease of genus Rhododendron (Basden and Helfer, 1995; Coyier, 1986; Kenyon, 1995). Although PM is known to cross-infect broad taxonomic groups within the genus (Beales, 1997; Galle, 1987), different disease symptoms are seen on deciduous azaleas (subgenus Pentanthera) and broad-leaved evergreen rhododendrons (subgenus Hymenanthes), and different causal organisms may be involved. Although three fungal genera (Microsphaera, Sphaerotheca, and Erysiphe) have generally been associated with PM symptoms in the genus Rhododendron, in the United States, deciduous azalea PM is generally considered to be caused by Erysiphe azalea U. Braun (Braun and Takamatsu, 2000). The disease is occasionally reported on evergreen azaleas

Received for publication 20 July 2009. Accepted for publication 8 Sept. 2009.

This research was paid for in part by the Minnesota Agricultural Experiment Station and The American Rhododendron Society.

${ }^{1}$ Former Graduate Student; currently Graduate Assistant.

${ }^{2}$ Director.

${ }^{3}$ Associate Professor.

${ }^{4}$ To whom reprint requests should be addressed; e-mailhokan017@umn.edu. be achieved by growing plants in exposed locations and using overhead rather than drip irrigation (Basden and Helfer, 1995; Galle, 1987; Helfer, 1994). Fungicides have been used to prevent and/or treat symptomatic plants with 10 commercial products currently being listed for use on azaleas (Greenbook ${ }^{\circledR}$ Turf and Ornamental Reference for Plant Protection Products, 2006). In the United States, nurseries and public gardens generally do not use fungicides for controlling Rhododendron PM, whereas some European growers apply fungicides up to 8 months per year to control the disease (Cox, 1993; Hall and Beales, 1998; Helfer, 1994). Fungicide resistance to Rhododendron spp. PM has been reported (Kenyon et al., 1998). High costs and environmental or human health risks associated with fungicide use make chemical control of PM an unattractive option.

The identification and use of PM-resistant cultivars would mitigate the need for chemical controls. Although deciduous azalea cultivars and species with resistance to PM exist, most of the cultivars named in the past 100 years are closely related and generally susceptible to PM, especially the Exbury hybrid group (Hardy, 1980). Identification of resistant germplasm that can be used in breeding programs would be an important step toward developing resistant cultivars.

Previous PM studies on deciduous azaleas have assessed disease severity and incidence. Hardy (1980) noted two previous lists of 27 "mildew-immune" and 21 "highly resistant" cultivars. Dutky (1990) observed two of five deciduous azalea cultivars to be "resistant" and "highly resistant" in Maryland. Basden and Helfer (1995) conducted a world survey of Rhododendron powdery mildews, which included deciduous azaleas. Of 309 surveys returned, $40 \%$ indicated no occurrence of PM, whereas $45 \%$ indicated PM occurred in their garden and/or nursery.

Two studies of deciduous azaleas at the Secrest Arboretum, Wooster, OH, reveal some of the difficulties inherent in field determinations of resistance to a disease that is influenced heavily by environmental conditions. Ford (1975) reported 27 of 61 (44\%) accessions to have "no disease." A later study by Cochran and Ellett (1990) reported 32 of $92(35 \%)$ accessions to be "disease-free" or to have a "slight occurrence." A comparison of the 39 cultivars evaluated in common between the two Secrest surveys reveals a majority of cultivars (26) retained their original ratings. Thirty-three percent of the cultivars had a change in disease rating between the 1975 and 1989 surveys. Twelve cultivars changed from a resistant rating to a susceptible rating, whereas one cultivar changed from a susceptible to resistant rating between the two studies.

The present study was initiated to provide a more robust test of PM disease on commercially available deciduous azaleas. Evaluations based on replicated trials over several years at multiple locations were used in an attempt to factor out environmental variability and obtain more consistent disease ratings. In 
addition, 23 of the field-tested azaleas were inoculated and screened in growth chamber experiments to determine whether this method of evaluation might prove to be more efficient than, but still predictive of, traditional field testing. Resistance screening in growth chambers (Barbetti and Nichols, 1991; Doster and Schnathorst, 1985) or other controllable environments such as greenhouses (Nelson et al., 1996) has been used successfully in other plant genera to identify highly susceptible cultivars.

\section{Materials and Methods}

Field experiments. In Apr. 2002, dormant, 15 to $30 \mathrm{~cm}$ tall, deciduous azalea plants were obtained from commercial nurseries: Briggs Nursery, Inc. (Olympia, WA), Girard Nurseries (Geneva, OH), Greer Gardens, Inc. (Eugene, OR), and Rare Find Nursery (Jackson, NJ). In
mid-May 2002, 41 cultivars (Table 1) were planted in a randomized complete block design at The Holden Arboretum's David G. Leach Research Station in Madison, $\mathrm{OH}$, and at the Minnesota Landscape Arboretum in Chanhassen, MN. At both sites, blocks consisted of four adjacent rows, each containing the 41 cultivars.

The Minnesota site was removed as a result of flooding in July 2002. Plants were transferred to 20 - to $25-\mathrm{cm}$ pots containing 1:1 peat:composted pine bark and grown under shadecloth for the remainder of the 2002 growing season. Potted plants were overwintered in cold storage and planted in a new site at the Horticultural Research Center in Excelsior, MN, in May 2003. Plants that did not survive the 2002 season were replaced at both locations.

Azaleas at both sites were watered as needed with drip irrigation and occasionally

Table 1 . Powdery mildew disease ratings on 41 deciduous azalea cultivars grown in field trials at two locations and evaluated for 2 to 3 years. $^{z}$

\begin{tabular}{|c|c|c|c|c|c|c|c|}
\hline \multirow[b]{3}{*}{ Cultivar } & \multirow{2}{*}{\multicolumn{2}{|c|}{ Mean disease rating ${ }^{y}$}} & \multicolumn{5}{|c|}{ Disease rating by location-year } \\
\hline & & & \multirow{2}{*}{$\begin{array}{l}\text { Ohio } \\
2002\end{array}$} & \multirow{2}{*}{$\begin{array}{l}\text { Ohio } \\
2003\end{array}$} & \multirow{2}{*}{$\begin{array}{l}\text { Ohio } \\
2004\end{array}$} & \multirow{2}{*}{$\begin{array}{l}\text { Minnesota } \\
2003\end{array}$} & \multirow{2}{*}{$\begin{array}{l}\text { Minnesota } \\
2004\end{array}$} \\
\hline & $\mathrm{N}^{\mathrm{x}}$ & Score & & & & & \\
\hline Fragrant Star & 19 & 1.00 & 1.00 & 1.00 & 1.00 & 1.00 & 1.00 \\
\hline Garden Party & 19 & 1.00 & 1.00 & 1.00 & 1.00 & 1.00 & 1.00 \\
\hline Millennium & 16 & 1.00 & $\mathrm{NA}^{\mathrm{w}}$ & 1.00 & 1.00 & 1.00 & 1.00 \\
\hline Parade & 17 & 1.00 & 1.00 & 1.00 & 1.00 & 1.00 & 1.00 \\
\hline Popsicle & 20 & 1.00 & 1.00 & 1.00 & 1.00 & 1.00 & 1.00 \\
\hline June Flame & 20 & 1.00 & 1.00 & 1.00 & 1.00 & 1.00 & 1.00 \\
\hline Snowbird & 20 & 1.05 & 1.00 & 1.00 & 1.00 & 1.25 & 1.00 \\
\hline Magic & 17 & 1.05 & 1.00 & 1.00 & 1.25 & 1.00 & 1.00 \\
\hline Late Lady & 18 & 1.10 & 1.00 & 1.00 & 1.00 & 1.00 & 1.50 \\
\hline Pink and Sweet & 19 & 1.10 & 1.25 & 1.00 & 1.25 & 1.00 & 1.00 \\
\hline Lollipop & 13 & 1.13 & NA & 1.00 & 1.00 & 1.50 & 1.00 \\
\hline Jane Abbott & 20 & 1.55 & 1.00 & 1.50 & 2.75 & 1.25 & 1.25 \\
\hline Northern Hi-Lights & 20 & 1.75 & 1.50 & 1.00 & 2.00 & 1.75 & 2.50 \\
\hline Homebush & 20 & 2.25 & 4.00 & 1.00 & 3.25 & 1.25 & 1.75 \\
\hline Golden Lights & 15 & 2.30 & 1.75 & 2.00 & 3.00 & 1.25 & 3.50 \\
\hline Apricot Surprise & 15 & 2.38 & 4.33 & 1.00 & 2.50 & 1.75 & 2.33 \\
\hline Jolie Madame & 20 & 2.50 & 2.75 & 3.75 & 3.75 & 1.25 & 1.00 \\
\hline Tri-Lights & 19 & 2.65 & 2.75 & 2.75 & 3.75 & 2.00 & 2.00 \\
\hline Crimson Tide & 19 & 2.73 & 4.00 & 2.00 & 4.00 & 1.00 & 2.67 \\
\hline Mandarin Lights & 20 & 2.80 & 3.75 & 1.50 & 4.00 & 1.50 & 3.25 \\
\hline Molalla Red & 17 & 2.98 & 4.75 & 1.00 & 4.50 & 1.67 & 3.00 \\
\hline White Lights & 18 & 3.30 & 3.75 & 2.00 & 4.25 & 1.50 & 5.00 \\
\hline Yellow Pom Pom & 17 & 3.38 & 4.00 & 2.00 & 4.67 & 2.75 & 3.50 \\
\hline Fireflash & 19 & 3.40 & 3.50 & 3.25 & 4.50 & 1.75 & 4.00 \\
\hline Fireball & 13 & 3.40 & 5.00 & 4.00 & 4.67 & 1.33 & 2.00 \\
\hline George Reynolds & 12 & 3.43 & 4.67 & 4.00 & 3.50 & 2.00 & 3.00 \\
\hline Klondyke & 19 & 3.45 & 5.00 & 3.50 & 4.00 & 1.75 & 3.00 \\
\hline Gibraltar & 20 & 3.50 & 5.00 & 1.75 & 5.00 & 1.75 & 4.00 \\
\hline Rosy Lights & 19 & 3.57 & 5.00 & 1.75 & 5.00 & 2.75 & 3.33 \\
\hline Orchid Lights & 20 & 3.60 & 5.00 & 1.25 & 4.75 & 2.25 & 4.75 \\
\hline Cannon's Double & 15 & 3.63 & 3.75 & 2.75 & 5.00 & 3.00 & 3.67 \\
\hline Western Lights & 19 & 3.63 & 5.00 & 1.75 & 4.75 & 3.00 & 3.67 \\
\hline Lemon Lights & 17 & 3.67 & 4.00 & 3.25 & 4.25 & 2.33 & 4.50 \\
\hline Cheerful Giant & 14 & 3.69 & 4.50 & 4.25 & 4.50 & 1.50 & $n a$ \\
\hline Mount Saint Helen & 20 & 3.80 & 5.00 & 2.75 & 5.00 & 1.50 & 4.75 \\
\hline Arneson Gem & 19 & 3.87 & 4.75 & 4.25 & 5.00 & 2.00 & 3.33 \\
\hline Strawberry Ice & 15 & 4.10 & 5.00 & 4.00 & 5.00 & 1.50 & 5.00 \\
\hline Arneson Ruby & 19 & 4.35 & 5.00 & 3.25 & 4.75 & 3.75 & 5.00 \\
\hline Orange Jolly & 18 & 4.40 & 5.00 & 3.75 & 5.00 & 3.25 & 5.00 \\
\hline Yellow Cloud & 17 & 4.62 & 5.00 & 4.75 & 5.00 & 3.33 & 5.00 \\
\hline Irene Koster & 16 & 4.85 & 5.00 & 5.00 & 5.00 & 4.25 & 5.00 \\
\hline Mean & 0 & 2.71 & 3.40 & 2.24 & 3.38 & 1.80 & 2.81 \\
\hline $\begin{array}{l}\text { Least significant } \\
\quad \text { difference }(P=0.05)\end{array}$ & 0 & 0.81 & & & & & \\
\hline
\end{tabular}

${ }^{2}$ Ratings represent the extent of mildew observed on abaxial leaf surfaces.

${ }^{y}$ Disease rating based on visual assessment of percent leaf area covered by powdery mildew: $1=0 \%, 2=$ $1 \%$ to $25 \%, 3=26 \%$ to $50 \%, 4=51 \%$ to $75 \%, 5=76 \%$ to $100 \%$

${ }^{\times} \mathrm{N}=$ total number of independent observations across locations $\times$ years (maximum of 20 ).

wA $=$ data not available with overhead watering to supply $\approx 2.5 \mathrm{~cm}$ of water per week. Fertilizer (18N-6P-12K + iron) at $0.9 \mathrm{~kg} / 90^{2} \mathrm{~m}$ was applied to the Ohio planting each spring. The Minnesota site was fertilized biweekly with liquid fertilizer (Excel ${ }^{\circledR}$ All Purpose 21-5-20; Scotts-Sierra Horticultural Products Company, Marysville, OH) at 100 ppm from mid-May to early-August each year.

Plants were exposed to naturally occurring PM inoculum. Whole plants were visually scored for average PM disease severity on the adaxial and abaxial leaf surfaces by the lead author using a 1 to 5 scale that rated the extent of disease on leaves: $1=$ no disease; $2=1 \%$ to $25 \%$ of leaf area infected; $3=26 \%$ to $50 \%$ of leaf area infected; $4=50 \%$ to $75 \%$ leaf area infected; and $5=$ greater than $75 \%$ of leaf area infected. In most moderately to highly susceptible plants, white powdery spots (mycelia and conidia) and discolored (purplish) patches on the leaf surface associated with the presence of the fungus were used to estimate the percent leaf area affected. Plants without any obvious disease symptoms were observed with a $16 \times$ hand lens to confirm whether they were resistant (mycelia and conidia absent) or susceptible (mycelia present). Data were collected in late August of 2002, 2003, and 2004 in Ohio and in late August of 2003 and 2004 in Minnesota. The Minnesota site was not scored in 2002. Statistical analysis was performed using the general linear model procedures in SAS (SAS Institute, Cary, NC). Correlation analyses were conducted with SPSS (SPSS Inc., Chicago, IL) and regression analysis was done with SigmaPlot (Systat Software Inc., San Jose, CA).

Growth chamber experiments. Five PMinfected outdoor screenhouse-grown plants each of 'Cannon's Double', 'Irene Koster', 'Klondyke', 'Western Lights', and 'White Lights' in $15-\mathrm{cm}$ pots were moved to a growth chamber (Environment Growth Chambers, Chagrin Falls, OH) on 17 Sept. 2003. Plants were grown under a $16-\mathrm{h}$ photoperiod, $92 \%$ relative humidity, $18{ }^{\circ} \mathrm{C}$ day $/ 16^{\circ} \mathrm{C}$ night conditions, and were bottom-watered as needed. Plants were fertilized with liquid fertilizer (Excel ${ }^{\circledR}$ All Purpose 21-5-20) at a rate of 100 ppm nitrogen on a biweekly basis. On 6 Jan. 2004, 10 dormant liners of 'Klondyke', 'Western Lights', and 'White Lights' were planted in $9-\mathrm{cm}$ pots containing 50:50 peat:perlite and placed in a growth chamber under the conditions described previously. On 27 Feb. 2004, after they were fully leafed out, plants were inoculated by touching them with randomly collected, infected leaves from the five cultivars originally placed in the growth chamber on 17 Sept. 2003.

On 27 Feb. and 7 May 2004 (two replicates of the experiment), four dormant liners of 27 cultivars (Table 2) were potted in $9-\mathrm{cm}$ pots with 50:50 peat:perlite. Plants were organized in a randomized complete block design. Randomization in two growth chambers, each including two blocks, resulted in four plants of each cultivar being evaluated at each time. Granules of Marathon ${ }^{\circledR}$ systemic insecticide (OHP, Inc., Mainland, PA) were applied to each plant at the lowest 
recommended rate 3 weeks after each planting to control aphids.

Plants were grown under the conditions described previously, except during the $3 \mathrm{~d}$ after inoculation, when day/night temperatures were increased to 20 and $18^{\circ} \mathrm{C}$, respectively, to promote infection. Conidia were dislodged from 'Klondyke', 'Western Lights', and 'White Lights' inoculum source plants by brushing infected leaves $3 \mathrm{~d}$ before inoculating the experiment to promote new conidia formation. On 4 Apr. and 1 June 2004, infected, randomly selected leaves of the source plants 'Klondyke', 'Western Lights', and 'White Lights' were touched to the adaxial and abaxial leaf surfaces of the two youngest, fully expanded leaves on the two tallest stems of each trial plant. Inoculated plants were scored on 4 May and 20 July 2004, respectively, as described for the field experiment. Statistical analysis followed that used for the field experiment.

\section{Results and Discussion}

Field experiments. Mean PM disease scores for the abaxial leaf surfaces of each cultivar are shown in Table 1 for the five location-year samplings. Overall disease severity (across years and locations) was significantly higher for the abaxial (2.71) than the adaxial (1.87) leaf surface, $(P<0.01, t$ test, data not shown). Disease ratings on the two leaf surfaces were positively correlated $\left(r^{2}=0.62, P<0.01\right)$. Because field plants often have low adaxial and high abaxial disease ratings, we considered abaxial scores to be a more conservative estimate of disease response because they are less likely to yield false-negative scores, i.e., plants mistakenly scored as resistant. Several previous studies showed similar results (Coyier, 1986; Kenyon, 1995; Kenyon et al., 1994, 2002; Strider, 1976) where more intense disease severity was also observed on the abaxial leaf surface. Henceforth, discussions concerning results of the field trial will be limited to those from abaxial leaf surface scores.

Sources of variation. Significant differences in powdery mildew severity on cultivars were observed along with large environmental effects resulting from location and year (Table 3). Variation in disease severity appeared to be mostly the result of year-to-year (seasonal) effects, which accounted for $57.4 \%$ of the total variation (mean square), followed by site effects $(24.0 \%)$ and cultivar effects $(13.7 \%)$. Small but significant portions of the variation were attributed to cultivar-by-location (1.4\%) and cultivar-by-year $(1.7 \%)$ interactions.

Numerous environmental factors influencing resistance have been implicated in PM resistance (reviewed by Beales, 1997) such as temperature (Yarwood et al., 1954), light (Schnathorst, 1959; Yarwood, 1936), humidity (Harris and Manners, 1983), and free water (Manners and Hossain, 1963; Yarwood, 1936). In this study, the largest source of variation in disease ratings (over $80 \%$ ) was accounted for by location and year effects (Table 3 ). The lower average scores at the Minnesota site (2.17) versus the Ohio site (2.96) across years

Table 2. Mean powdery mildew disease ratings for adaxial leaf surfaces of 27 deciduous azalea cultivars in the two growth chamber (GC) experiments.

\begin{tabular}{|c|c|c|c|}
\hline Cultivar & $\begin{array}{c}\text { Expt. 1 } \\
\text { Adaxial }^{z}\end{array}$ & $\begin{array}{l}\text { Expt. } 2 \\
\text { Adaxial }\end{array}$ & $\begin{array}{c}\text { GC Means } \\
\text { Adaxial }\end{array}$ \\
\hline Millennium & 1.25 & 1.25 & 1.25 \\
\hline Parade & 1.25 & 1.50 & 1.38 \\
\hline Tri-Lights & 1.50 & 1.50 & 1.50 \\
\hline Lemon Lights & 1.50 & 1.75 & 1.63 \\
\hline Fragrant Star & 1.75 & 1.75 & 1.75 \\
\hline Mandarin Lights & 2.00 & 2.00 & 2.00 \\
\hline Northern Hi-Lights & 1.25 & 2.75 & 2.00 \\
\hline Snowbird & 2.00 & 2.00 & 2.00 \\
\hline Lollipop & 2.25 & 2.00 & 2.13 \\
\hline Golden Lights & 2.00 & 3.00 & 2.50 \\
\hline Colonel Mosby & 2.25 & 3.00 & 2.63 \\
\hline Fireball & 3.25 & 2.75 & 3.00 \\
\hline Homebush & 2.75 & 3.75 & 3.25 \\
\hline Emma Sanson & 3.25 & 4.00 & 3.63 \\
\hline Mount Saint Helen & 3.50 & 3.75 & 3.63 \\
\hline Cannon's Double & 4.00 & 3.75 & 3.88 \\
\hline Klondyke & 3.75 & 4.00 & 3.88 \\
\hline Orchid Lights & 3.50 & 4.75 & 4.13 \\
\hline Yellow Cloud & 4.25 & 4.25 & 4.25 \\
\hline Rosy Lights & 4.00 & 4.75 & 4.38 \\
\hline Umpqua Queen & 4.25 & 4.38 & 4.32 \\
\hline Western Lights & 3.75 & 5.00 & 4.38 \\
\hline Centennial & 4.75 & 4.25 & 4.50 \\
\hline Gibraltar & 4.75 & 4.25 & 4.50 \\
\hline Irene Koster & 4.25 & 5.00 & 4.63 \\
\hline White Lights & 4.50 & 5.00 & 4.75 \\
\hline Cheerful Giant & 5.00 & 5.00 & 5.00 \\
\hline Replicate means & 3.06 & 3.38 & 3.22 \\
\hline Least significant difference $(P=0.05)$ & 0.98 & 1.00 & 0.64 \\
\hline
\end{tabular}

${ }^{\mathrm{z}}$ Disease rating based on visual assessment of percent leaf area covered by powdery mildew: $1=0 \%, 2=$ $1 \%$ to $25 \%, 3=26 \%$ to $50 \%, 4=51 \%$ to $75 \%, 5=76 \%$ to $100 \%$.

(2003 to 2004) could be attributed to differences in rainfall, which was higher at the Minnesota site (15.5 and 21.2 inches) than the Ohio site (13.9 and 17.7 inches) over the April to August growing seasons. Powdery mildew conidia need near $100 \%$ relative humidity to germinate, but free water, i.e., rainfall and overhead irrigation, impedes the PM infection and disease progression process by washing away spores and mycelium (Coyier, 1986; Manners and Hossain, 1963; Yarwood, 1936).

Mean temperatures for the 2003 to 2004 seasons at the two locations differed little (73.3 and $70.4^{\circ} \mathrm{F}$ in Minnesota and 70.9 and $71 .{ }^{\circ} \mathrm{F}$ in Ohio) and may not have been as large a factor as rainfall in causing environmental variation in disease ratings. The higher disease ratings at the Ohio site may also have resulted from close proximity of that trial to an azalea display garden containing numerous susceptible cultivars that potentially produced higher levels of inoculum. In addition, the Ohio site received some partial shading that may have allowed for increased levels of humidity, thus contributing to a more favorable environment for PM infection and development.

Genotype comparisons. The overall disease severity score for the 41 cultivars was 2.71 , indicating that the collection was mostly susceptible (Table 1). Six genotypes (14.6\%), 'Fragrant Star', 'Garden Party', 'Millennium', 'Parade', 'Popsicle', and 'June Flame', showed no PM symptoms at either location in any of the three field seasons, suggesting resistant deciduous azalea cultivars exist. Another group of five genotypes with mean
Table 3. Analysis of variance in powdery mildew ratings of abaxial leaf surface for 41 deciduous azaleas evaluated at two field locations for up to 3 years.

\begin{tabular}{lrcc}
\hline & & \multicolumn{2}{c}{ Abaxial disease rating } \\
\cline { 3 - 4 } Source & df & Mean squares & F value \\
\hline Cultivar (C) & 40 & 21.1 & $38.1^{* *}$ \\
Replication & 3 & 0.3 & 0.5 \\
Location (L) & 1 & 37.1 & $67.1^{* *}$ \\
Year (Y) & 2 & 88.6 & $160.1^{* *}$ \\
C*L & 40 & 2.2 & $4.0^{* *}$ \\
C*Y & 78 & 2.6 & $4.8^{* *}$ \\
L*Y & 1 & 1.7 & 3.1 \\
Error & 563 & 0.6 & \\
\hline
\end{tabular}

**Significant at the $P=0.01$ level.

scores ranging from 1.05 to $1.13(12.2 \%)$, 'Snowbird', 'Magic', 'Late Lady', 'Pink and Sweet', and 'Lollipop', could be considered highly resistant because they exhibited mild symptoms in one of the five year-location samplings and were otherwise disease-free. The remaining genotypes $(73.2 \%)$ had disease severity scores ranging from 1.55 to 4.85 and were considered moderately to highly susceptible. Despite the considerable environmental effect, cultivar disease ratings were significantly correlated across years and locations with $r$ values ranging from 0.55 to 0.92 (Table $4)$. The correlations suggest that overall response of a genotype in a given year to one set of conditions is a reasonable predictor of its performance under another set of circumstances in another year.

Current versus previous reports of genotypes in common. Ten cultivars evaluated in our study were rated in previous studies 
(Table 5). These cultivars received resistant, susceptible, or contradictory disease ratings in those studies. In our study, none of the 10 cultivars were rated as resistant with the scores ranging from 2.25 to 4.85 . Regarding the cultivars rated in the two evaluations at the Secrest Arboretum that received contradictory ratings, i.e., 'Klondyke' and 'Gibralter', our field results support the initial susceptible rating by Ford (1975). Cultivars that were previously assessed as resistant, e.g., 'Homebush', 'Jolie Madame', 'Fireball', and 'Crimson Tide', clearly can be susceptible under some circumstances such as the environmental conditions or pathogen populations encountered in this study.

Different methodologies could account for the discrepancies among studies. Previous cultivar assessments were based on single-year, single-site data (Hardy, 1980) or multiple-year, single-site ratings (Cochran and Ellett, 1990; Ford, 1975). Disease ratings in these reports have been based on incidence (resistant versus susceptible) or severity (numerical scale reflecting leaf area infected by PM). None of these garden evaluations included a replicated field design, and because no details are given about which leaf surface was scored, it is possible that the PM ratings were derived differently. In our study, 'Jolie Madame' had a large difference in adaxial and abaxial leaf scores in Ohio (1.42 versus 3.42), underscoring the importance of choosing the more diseased surface as a conservative estimate of resistance. If adaxial scores were used in the Cochran and Ellett (1990) study, that might account for the resistant rating given to 'Jolie Madam'. The previous resistant rating attributed to 'Fireball' came from an article by Hardy (1980) in which the author states the rating is the result of "observations" and should not be considered "infallible." Given the anecdotal nature of the report, the susceptible rating for 'Fireball' in the present study is likely to be more accurate.

Our results (Table 1) demonstrate that consistency in disease ratings across years and locations was highest at the extremes of the disease rating scale, which included the most resistant and most susceptible cultivars. Genotypes with midvalue ratings (mean leaf scores of 2 to 3 ) were the most variable; depending on when and where they were evaluated, they appeared either resistant or susceptible. Such variability, which is strongly influenced by environmental conditions, highlights the necessity of repeated observations (locations, years, and replications) for such field studies of PM disease.

Although the fungal organism(s) responsible for PM disease on deciduous azalea in this study has not been definitively identified, and no knowledge of race structure exists for the azalea-PM pathosystem, it is possible that different races account for some of the difference in resistance noted between previous and current reports and even between sites in the current study. Multiple races have been identified in several horticultural PM pathosystems, including rose (Rosa $\times$ hybrida) (Linde and Debener, 2003), apple (Malus domestica

Table 4. Correlations of powdery mildew ratings of abaxial leaf surfaces on 41 deciduous azalea cultivars across locations and years.

\begin{tabular}{lcccc}
\hline & Ohio 2003 & Ohio 2004 & Minnesota 2003 & Minnesota 2004 \\
\hline Ohio 2002 & $0.62^{* *}$ & $0.92^{* *}$ & $0.63^{* *}$ & $0.79^{* *}$ \\
Ohio 2003 & & $0.70^{* *}$ & $0.55^{* *}$ & $0.61^{* *}$ \\
Ohio 2004 & & $0.66^{* *}$ & $0.85^{* *}$ \\
Minnesota 2003 & & & $0.72^{* *}$ \\
\hline
\end{tabular}

**Pearson correlation significant at the 0.01 level (two-tailed).

Borkh.) (Urbanietz and Dunemann, 2005), and melon (Cucumis melo L.) (McCreight, 2006).

Growth chamber experiments. Variations in disease ratings in the growth chamber had a larger genetic $(60 \%)$ than environmental (28\%) component (Table 6). This was in contrast to the results from the field where environmental factors accounted for $80 \%$ of the variation. The controlled environment of the growth chambers may therefore provide a more accurate estimate of disease symptoms and host resistance than field studies.

Like in the field study, adaxial and abaxial disease severity ratings were positively correlated ( $r=0.91, P<0.01$ for both Expts. 1 and 2). Unlike the field study, symptoms were more pronounced on the upper (adaxial) surface of leaves, so the overall mean adaxial disease severity score, 3.22 , was significantly higher than the mean abaxial score, 2.11 ( $P<$ $0.01, t$ test). Adaxial growth chamber scores were used for comparisons in this analysis because they provide a more conservative estimate of disease resistance. Several other researchers have demonstrated that PM severity is higher for the abaxial leaf surface in rhododendron plants grown outdoors, whereas plants grown in the growth chamber or other controlled environments show more severe adaxial symptoms (Coyier, 1986; Kenyon, 1995; Kenyon et al., 1994, 2002, Strider, 1976). Kenyon (1995) attributed higher adaxial disease scores in tissue-cultured material to a thinner leaf cuticle and epidermis under a low-light regime. The more severe adaxial leaf symptoms observed in our growth chamber experiments could be caused by similar leaf surface characteristics as a result of lower levels of irradiance than in the field. In addition, factors such as bottom-watering (lack of conidial "washing" by overhead water), the constant high relative humidity $(92 \%)$ in the growth chamber, and the presence of fans circulating spores within a closed chamber would all favor disease development in general and adaxial symptoms in particular compared with field-grown plants.

All genotypes developed PM symptoms in the growth chamber (Table 2). Symptoms appeared as early as $7 \mathrm{~d}$ after inoculation and infected areas enlarged quickly. Although all genotypes became infected, they differed significantly for levels of PM infection $(P \leq 0.0001$; Table 6$)$, indicating that variation in PM disease response was detectable in the growth chamber. Although the PM fungus infected all cultivars, 'Millennium', 'Parade', 'Tri-Lights', 'Lemon Lights', 'Fragrant Star', 'Mandarin Lights', 'Northern HiLights', and 'Snowbird' were the most resistant with scores less than or equal to 2 .
Table 5. Comparison of powdery mildew disease ratings from this study and those determined in earlier studies.

\begin{tabular}{lcc}
\hline Cultivar & $\begin{array}{c}\text { Present } \\
\text { study }^{z}\end{array}$ & $\begin{array}{c}\text { Previous } \\
\text { reports }\end{array}$ \\
\hline Homebush & 2.25 & $\mathrm{R}^{4}$ \\
Jolie Madame & 2.50 & $\mathrm{R}^{5}$ \\
Crimson Tide & 2.73 & $\mathrm{R}^{5}$ \\
Fireball & 3.40 & $\mathrm{R}^{4}$ \\
George Reynolds & 3.43 & $\mathrm{~S}^{3,5}$ \\
Klondyke & 3.45 & $\mathrm{~S}^{3} \mathrm{R}^{4}$ \\
Gibraltar & 3.50 & $\mathrm{R}^{1,2,4} \mathrm{~S}^{3}$ \\
Mount Saint Helen & 3.80 & $\mathrm{~S}^{5}$ \\
Strawberry Ice & 4.10 & $\mathrm{~S}^{3}$ \\
Irene Koster & 4.85 & $\mathrm{~S}^{1}$ \\
\hline
\end{tabular}

${ }^{z}$ Ratings based on visual assessment of percent leaf area covered by mildew on a scale of $1(0 \%)$ to 5 ( $75 \%$ or greater).

yPrevious reports, $\mathrm{R}=$ resistant, $\mathrm{S}=$ susceptible. Superscript numbers refer to the following references ${ }^{1}$ Basden and Helfer, 1995; ${ }^{2}$ Dutky, 1990; ${ }^{3}$ Ford, 1975; ${ }^{4}$ Hardy, 1980; ${ }^{5}$ Cochran and Ellett, 1990. A variety of rating systems were used (see text).

Table 6. Analysis of variance for adaxial disease ratings in the growth chamber experiment (Type III error) including df, mean squares (MS), and $\mathrm{F}$ values.

\begin{tabular}{lrrc}
\hline & & \multicolumn{2}{c}{ Adaxial } \\
\cline { 3 - 4 } Source & df & \multicolumn{1}{c}{ MS } & F value \\
\hline Cultivar (C) & 26 & 12.11 & $26.97^{* *}$ \\
Replication (R) & 3 & 0.81 & 1.80 \\
Trial (T) & 1 & 5.67 & $12.63^{*}$ \\
C*R & 78 & 0.40 & 0.88 \\
C*T & 26 & 0.63 & 1.41 \\
Error & 81 & 0.45 & \\
**, *Statistical significance at the $P=0.0001$ and
\end{tabular}

0.001 levels, respectively.

Relative cultivar performance in field and growth chamber experiments. The growth chamber experiment was initiated to assess the feasibility of speeding plant disease resistance screening, controlling some of the environmental variation found in field experiments, and to assess the potential for growth chamber results to predict field performance. Twenty-three of the 27 cultivars used in the growth chamber experiments were also included in the field trials. Regression analysis (Fig. 1) revealed a significant relationship $\left(r^{2}=0.62, P \leq 0.01\right)$ between growth chamber and field leaf disease symptoms on the group of cultivars common to both experiments. Although growth chamber or greenhouse experiments have been used effectively to complement field experiments (Barbetti and Nichols, 1991; Doster and Schnathorst, 1985; Nelson et al., 1996; Scott et al., 1976), differences in cultivar performances between 


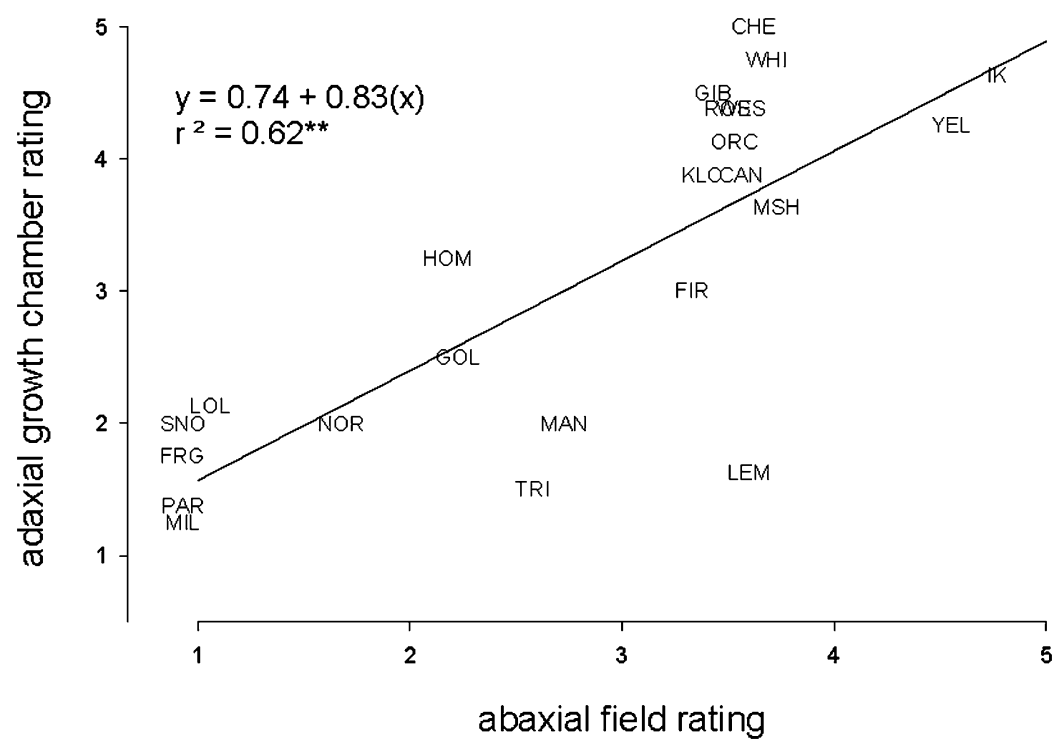

Fig. 1. Correspondence between powdery mildew disease ratings obtained from field trials (abaxial) and from growth chamber (adaxial) ratings. Twenty-three deciduous azaleas were used for comparison.

the two methods of evaluation have also been reported (Leath et al., 1991).

\section{Conclusions}

Forty-one deciduous azalea genotypes were assessed for PM severity in field experiments and 23 of these same cultivars were assessed in growth chamber experiments. The two-location, 3-year field study is the first long-term experiment designed to assess PM severity of deciduous azalea cultivars. Six cultivars remained disease-free throughout the field study, indicating that resistance for the disease does exist in deciduous azalea germplasm. Interestingly, four of these six disease-free cultivars were products of the Mezzitt breeding program in West Hopkinton, MA. All but 'Parade' is fully derived from North American species with 'Parade' being half North American species. In a related study of 126 deciduous azalea genotypes evaluated in five botanic gardens and arboreta over three seasons, four North American species, $R$. arborescens, $R$. canadense, $R$. canescens, and $R$. vaseyi, exhibited no disease in any of the locations (Long et al., unpublished data). The North American species as a group showed more resistance than the Asian and Eurasian species evaluated suggesting North American species may be a good source of resistance to PM.

Three of the field resistant cultivars were among the five least symptomatic in the growth chamber study, although overall PM scores were higher in the growth chamber. A significant, positive correlation between growth chamber and field disease symptoms suggests that controlled environments could prove useful to breeders as a means of reducing environmental variables and speeding up the disease screening process. Disease screening could be done at a point before field space is committed to the plants and the work could be completed in the late winter, early spring before the typical field season begins. The high level of environmental variation (site and year) noted in the field experiments, coupled with the potentially variable nature of the PM pathogen, has implications for resistance breeding. The costs of determining the physiological race structure for a pathogen that may comprise dozens of races is prohibitive for a minor crop such as deciduous azalea. The most cost-effective approach for determining resistance in variable environments and under pressure from alternate races of the PM pathogen is to place genotypes in replicated trials in multiple environments. Such trials should be conducted for advanced selections in the breeding program.

Currently, little is known about the nature of resistance of deciduous azalea to PM. Several anatomical factors, including lignin content (Royle, 1976), cuticle thickness (Heintz and Blaich, 1989; Jhooty and McKeen, 1965; Mence and Hildebrandt, 1966), and hairs (Butt, 1971), could play a role in resistance and could be investigated. Interestingly, many of the resistant genotypes in our study have glaucous leaves, suggesting that cuticular waxes may play a role in defense against PM. Although cuticular waxes have been associated with insect resistance in azalea (Chappell and Robacker, 2006), no role for cuticular waxes in disease resistance has been investigated in azalea. Host resistance factors, including phytoalexin activity (Oku et al., 1975), and pathogen factors, including the presence of differing mating types (Leath et al., 1991), could be investigated. We have noted the presence of necrotic lesions suggestive of a hypersensitive response on some azalea genotypes. No investigations into the possibility of partial resistances in deciduous azalea germplasm have been reported. Finally, the role of plant stress (Schnathorst, 1959) and juvenility (Wright and Heale, 1984) would be interesting aspects of the host disease response to investigate.

\section{Literature Cited}

Barbetti, M.J. and P.G.H. Nichols. 1991. Susceptibility of subterranean clover varieties to powdery mildew under controlled environment and field conditions. Aust. J. Exp. Agr. 31:81-84.

Basden, N. and S. Helfer. 1995. World survey of Rhododendron powdery mildews. J. Amer. Rhododendron Soc. 49:147-156.

Beales, P.A. 1997. The epidemiology and biology of Rhododendron powdery mildew. $\mathrm{PhD}$ diss., Univ. Hertfordshire, Hertfordshire, UK. Abstr. 53665174.

Braun, U. and S. Takamatsu. 2000. Phylogeny of Erysiphe, Microsphaera, Uncinula (Erysipheae) and Cystotheca, Podosphaera, Sphaerotheca (Cystotheceae) inferred from rDNA ITS sequences-Some taxonomic consequences. Schlechtendalia 4:1-33.

Butt, D.J. 1971. Apple powdery mildew (Podosphaera leucotricha). Report East Malling Res. Stat. p. 107-109.

Chappell, M. and C. Robacker. 2006. Leaf wax extracts of four deciduous azalea genotypes affect azalea lace bug (Stephanitis pyrioides Scott) survival and behavior. J. Amer. Soc. Hort. Sci. 131:225-230.

Cochran, K.D. and C.W. Ellett. 1990. Evaluation of powdery mildew severity on deciduous azaleas at the Secrest Arboretum-1989. Ohio Agr. Res. Dev. Ctr. Res. Spec. Circ. 135:54-58.

Cox, P.A. 1993. The cultivation of Rhododendron. B.T. Batsford Ltd., London, UK.

Coyier, D.L. 1986. Powdery mildew, p. 24-25. In: Coyier, D.L. and M.K. Roane (eds.). Compendium of rhododendron and azalea diseases. APS Press, St. Paul, MN.

Doster, M.A. and W.C. Schnathorst. 1985. Comparative susceptibility of various grapevine cultivars to the powdery mildew fungus Uncinula necator. Amer. J. Enol. Viticult. 36:101104.

Dutky, E.M. 1990. Rhododendron and azalea cultivars-Disease susceptibility and resistance. Azalean. 12:38-39.

Farr, D.F., G.F. Bills, G.P. Chamuris, and A.Y Rossman. 1989. Fungi on plants and plant products in the United States. The American Phytopathological Society, St. Paul, MN

Ford, J.E. 1975. Performance of woody plants in the Secrest Arboretum. II. Heath family: Ericaceae. Ohio Agr. Res. Dev. Ctr. Res. Circ, 139(revised):42.

Galle, F.C. 1987. Azaleas. Timber Press, Portland, OR.

Greenbook ${ }^{\circledR}$ Turf and Ornamental Reference for Plant Protection Products. 2006. Vance Communication Corporation, New York, NY.

Hall, A.M. and P.A. Beales. 1998. The epidemiology and control of Rhododendron powdery mildew. Proc. 7th Intl Congr. Plant Pathol., Edinburgh, UK. 3:40

Hardy, J. 1980. Deciduous azaleas, part II asiatic species. Azalean. 2:1-4.

Harris, J.G. and J.G. Manners. 1983. Influence of relative humidity on germination and disease development in Erysiphe graminis. Trans. Br. Mycol. Soc. 81:605-611.

Heintz, C. and R. Blaich. 1989. Structural characters of epidermal cell walls and resistance to powdery mildew of different grapevine cultivars. Vitis 28:153-160.

Helfer, S. 1994. Rhododendron powdery mildews. Acta Hort. 364:155-160.

Holcomb, G.E. and D.M. Ferrin. 2006. First report of powdery mildew on azalea caused by Erysiphe azaleae in Louisiana. Plant Dis. 90:1263.

Jhooty, J.S. and W.E. McKeen. 1965. Studies on powdery mildew of strawberry caused by 
Sphaerotheca macularis. Phytopathology 55: 281-285.

Kenyon, D.M. 1995. The biology and pathogenic variation of Erysiphe species on Rhododendron. PhD diss. Univ. Strathclyde, Strathclyde, UK. Abstr. 52384895.

Kenyon, D.M., J. Brundin, G.R. Dixon, and S. Helfer. 1998. Investigation of the genetic diversity of Erysiphe sp. infecting Rhododendon spp. Proc. 7th Intl Congr. Plant Pathol., Edinburgh, UK. 2:126.

Kenyon, D.M., G.R. Dixon, and S. Helfer. 1994. Powdery mildew pathogens of Rhododendron. Acta Hort. 364:161.

Kenyon, D.M., G.R. Dixon, and S. Helfer. 2002. Effects of relative humidity, light intensity and photoperiod on the colony development of Erysiphe sp. on Rhododendron. Plant Pathol. 51:103-108.

Leath, S., P.L. Bruckner, and J.P. Wilson. 1991. Reaction of winter oat germplasm to an epidemic of oat powdery mildew. Plant Dis. 75: 807-809.

Linde, M. and T. Debener. 2003. Isolation and identification of eight races of powdery mildew of roses [Podosphaera pannosa (Wallr.: Fr.) de Bary] and the genetic analysis of the resistance gene Rpp1. Theor. Appl. Genet. 107:256-262.

Manners, J.G. and S.M.M. Hossain. 1963. Effect of temperature and humidity on conidial germination in Erysiphe graminis. Trans. Br. Mycol. Soc. 46:225-234.

McCreight, J.D. 2006. Melon-powdery mildew interactions reveal variation in melon cultigens and Podosphaera xanthii races 1 and 2. J. Amer. Soc. Hort. Sci. 131:59-65.

Mence, M.J. and A.C. Hildebrandt. 1966. Resistance to powdery mildew in rose. Ann. Appl. Biol. 58:309-320

Nelson, M.D., W.D. Gubler, and D.V. Shaw. 1996. Relative resistance of 47 strawberry cultivars to powdery mildew in California greenhouse and field experiments. Plant Dis. 80:326-328.

Oku, H., S. Ouchi, T. Shiraishi, and T. Baba. 1975. Local accumulation of pisatin in tissues of pea seedlings. Phytopathology 65:1263-1267.

Royle, D.J. 1976. Structural features of resistance to plant disease. Academic Press, New York, NY.
Schnathorst, W.C. 1959. Heterothallism in the lettuce strain of Erysiphe cichoracearum. Mycologia 51:708-711.

Scott, D.H., A.D. Draper, and J.L. Maas. 1976 Mass screening of young strawberry seedling for resistance to Phytophthora fragaria Hickman. HortScience 11:257-258.

Strider, D.L. 1976. Increased prevalence of powdery mildew of azalea and rhododendron in North Carolina. Plant Dis. Rptr. 60:149-151.

Urbanietz, A. and F. Dunemann. 2005. Isolation, identification and molecular characterization of physiological races of apple powdery mildew (Podosphaera leucotricha). Plant Pathol. 54: 125-133.

Wright, A.J. and J.B. Heale. 1984. Adult plant resistance to powdery mildew (Erysiphe graminis) in three barley cultivars. Plant Pathol. 33:493-502.

Yarwood, C.E. 1936. The diurnal cycle of the powdery mildew Erysiphe polygoni. J. Agr. Res. 52:645-657.

Yarwood, C.E., S. Sidky, M. Cohen, and V. Santilli. 1954. Temperature relations of powdery mildews. Hilgardia 22:603-622. 